\title{
Mycorrhizal colonization of chenopods and its influencing factors in different saline habitats, China
}

\author{
ZHAO Yinan, YU Hongqing, ZHANG Tao ${ }^{*}$, GUO Jixun ${ }^{*}$ \\ Institute of Grassland Science, Northeast Normal University, Key Laboratory of Vegetation Ecology, Ministry of Education, \\ Changchun 130024, China
}

\begin{abstract}
Chenopodiaceae is one of the most important families in arid and saline environments. Several studies have observed the mycorrhizal structure in Chenopodiaceae plants (i.e., chenopods), but the mycorrhizal colonization status of chenopods in saline habitats and the influencing factors are still not well understood. The mycorrhizal colonization of twenty chenopod species in three different saline habitats (a saline alkaline meadow in the Songnen Plain of northeastern China, a saline desert in the Junggar Basin of northwestern China, and a saline alpine meadow in the Tibetan Plateau of western China) and the chenopod-associated environmental factors (including soil moisture, soil available phosphorous (P) concentration, $\mathrm{pH}$, and salt content) were analyzed. Our results showed that approximately $60 \%$ of the studied chenopods were colonized by arbuscular mycorrhizal (AM) fungi with a colonization percentage ranging from $5 \%$ to $33 \%$. Structural analysis of mycorrhizal association indicated that vesicles were quite common, while arbuscules and hyphal coils were relatively rare. In addition, a positive correlation between mycorrhizal colonization rate and soil electrical conductivity $(r=0.920$, $P<0.01)$ and two negative correlations of mycorrhizal colonization rates with soil moisture $(r=-0.818$, $P<0.01)$ and the soil available $\mathrm{P}$ concentration $(r=-0.876, P<0.01)$ confirmed that mycorrhizal colonization rate in the roots of chenopods was environment-dependent.
\end{abstract}

Keywords: adaptation; arbuscular mycorrhizal fungi; Chenopodiaceae; salinization; restoration

Citation: ZHAO Yinan, YU Hongqing, ZHANG Tao, GUO Jixun. 2017. Mycorrhizal colonization of chenopods and its influencing factors in different saline habitats, China. Journal of Arid Land, 9(1): 143-152. doi: 10.1007/s40333-016-0027-6

\section{Introduction}

Arbuscular mycorrhizal (AM) fungi are the most important members of the soil microbiota and can form mycorrhizal symbionts with the majority of higher plants (Smith and Read, 2008). A large number of studies have found that AM fungi can improve plant growth by increasing uptake of nutrients such as phosphorus and nitrogen (van der Heijden et al., 2006; Hodge and Fitter, 2010; Miransari, 2011; Smith et al., 2011; Nazeri et al., 2014) and thus can improve food security and ecosystem stability (Mohan et al., 2014; Wagg et al., 2014; Rodriguez and Sanders, 2015). AM fungi can promote host plant resistance to adverse conditions, such as drought stress (Porcel and Ruiz-Lozano, 2004; Ruíz-Sánchez et al., 2011; Shi et al., 2015), high salinity (Daleo et al., 2007; Evelin et al., 2009; Chandrasekaran et al., 2014) and nutrient deficiencies (Smith, 2009; Whiteside et al., 2012). Even worse, some plants cannot survive in certain extreme environments without AM fungi (Pennisi, 2004).

Some species in the family Chenopodiaceae are rather tolerant to high salinity and/or to

\footnotetext{
*Corresponding author: ZHANG Tao (E-mail: zhangt946@nenu.edu.cn); GUO Jixun (E-mail: gjixun@nenu.edu.cn) Received 2016-07-10; revised 2016-10-31; accepted 2016-11-22

(C) Xinjiang Institute of Ecology and Geography, Chinese Academy of Sciences, Science Press and Springer-Verlag Berlin Heidelberg 2017
} 
drought stress and/or to soil-nutrient deficiencies and many of them are of great economic and ecological values (Glenn et al., 1991). An increasing number of studies have found that many chenopods can be colonized by AM fungi (Allen, 1983; Allen and Allen, 1990; Sigüenza et al., 1996; Aguilera et al., 1998; Shi et al., 2006; Wilde et al., 2009; Aleman and Tiver, 2010; Zhang et al., 2012). Several studies have further shown that AM fungi can improve the growth of the chenopod species Atriplex canescens (Williams et al., 1974), Arthrocnemum indicum and Suaeda maritime (Sengupta and Chaudhuri, 1990), Atriplex nummularia (Asghari et al., 2005; Plenchette and Duponnois, 2005) and Ceratocarpus arenarius (Zhang et al., 2012). However, the colonization status of AM in chenopods in different saline gradients of natural environments and the influencing factors are not well understood (Hirrel et al., 1978; Smith and Read, 2008). The aims of the study are to analyze the mycorrhizal colonization status of chenopods grown in different saline conditions and to elucidate the environmental factors affecting the establishment of mycorrhizal association between chenopods and AM fungi.

\section{Materials and methods}

\subsection{Study sites}

Three typical saline sites were studied (Fig. 1) and they are: a saline alkaline meadow (site I), a salt desert (site II) and a saline alpine meadow (site III).

\section{Site I}

Experimental site I is situated in a typical soda saline meadow in the Songnen Plain $\left(44^{\circ} 45^{\prime} \mathrm{N}\right.$, $123^{\circ} 45^{\prime} \mathrm{E}$; $150-200 \mathrm{~m}$ a.s.1.), Jilin Province of northeastern China. The annual mean temperature in the meadow is about $5.0^{\circ} \mathrm{C}$. The mean annual precipitation is approximately $400 \mathrm{~mm}$ mainly occurring during the summer season and the annual evaporation is up to $2000 \mathrm{~mm}$. The soil $\mathrm{pH}$ is $8.0-10.0$ and soil organic matter content is $3 \%-4 \%$.

\section{Site II}

Experimental site II is situated in a typical saline desert in the southern edge of Junggar Basin $\left(34^{\circ} 09^{\prime}-49^{\circ} 08^{\prime} \mathrm{N}, 73^{\circ} 25^{\prime}-96^{\circ} 24^{\prime} \mathrm{E}\right.$; 500-1000 m a.s.1.), Xinjiang Uygur Autonomous Region of northwestern China. The annual mean temperature in the basin ranges from $-4^{\circ} \mathrm{C}$ to $9^{\circ} \mathrm{C}$. The mean annual precipitation is approximately $150 \mathrm{~mm}$ mainly occurring during the spring and autumn seasons and the annual evaporation is up to $3000 \mathrm{~mm}$. The soil $\mathrm{pH}$ is about 8.5 and the soil organic matter content is about $1 \%$.

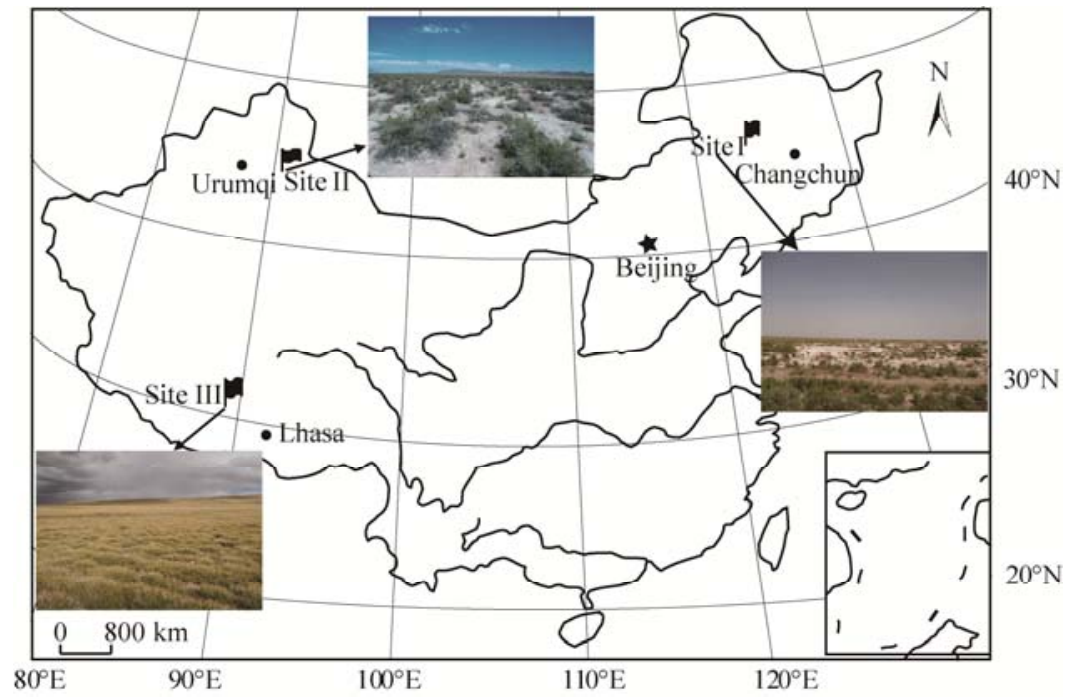

Fig. 1 Locations of three studied sites 


\section{Site III}

Experimental site III is situated in a typical alpine meadow in the western Tibetan Plateau $\left(30^{\circ} 57^{\prime}-31^{\circ} 51^{\prime} \mathrm{N}, 86^{\circ} 56^{\prime}-90^{\circ} 59^{\prime} \mathrm{E}\right.$; 4000-4500 m a.s.1.), Tibet Autonomous Region of western China. The annual mean temperature in the alpine meadow ranges from $3.0^{\circ} \mathrm{C}$ to $-1.2^{\circ} \mathrm{C}$ and the mean annual precipitation ranges from 100 to $200 \mathrm{~mm}$ mainly occurring in the summer season. The annual evaporation is up to $1500 \mathrm{~mm}$. Soil $\mathrm{pH}$ is $8-9$ and soil organic matter content is $1 \%-3 \%$.

\subsection{Plant and soil sampling}

Plants and soil were collected from the three experimental sites at the early growth stage (early May) and at the peak growth stage (middle July). According to the natural distribution and numbers of chenopod species in northeastern part (i.e., site I), northwestern part (i.e., site II) and western part (i.e., site III) of China, twenty common chenopod species were selected from these three experimental sites. From the experimental site I (i.e., Songnen meadow), 4 species were selected and they are: (A) Chenopodium glaucum, (B) Kochia scoparia, (C) Suaeda corniculata, and (D) Salsola komarovii. From the experimental site II (i.e., Junggar Basin), 12 species were selected and they are: (E) Salsol foliosa, (F) Salsola collina, (G) Petrosimonia sibirica, (H) Kalidium foliatum, (I) Halogeton glomeratus, (J) Salicornia europaea, (K) Atriplex tatarica, (L) Suaeda altissima, (M) Suaeda acuminate, (N) Suaeda physophora, (O) Suaeda microphylla, and (P) Suaeda salsa. From the experimental site III (i.e., Tibetan Plateau), 4 species were selected and they are: (Q) Polygonum fertile, (R) Chenopodium glaucum, (S) Chenopodium sp. and (T) Chenopodium quinoa. The topsoil $(1-2 \mathrm{~cm})$ was removed before sampling. The plants were dug out with a trowel to ensure that the roots remained connected to the shoots after sampling. The roots and rhizosphere soil were carefully separated and the collected samples were then taken to the laboratory. Half of the fresh root was used to measure mycorrhizal colonization, the other half was cut into small pieces, oven-dried overnight at $70^{\circ} \mathrm{C}$ for $48 \mathrm{~h}$, and stored in air-tight containers for AM fungal DNA processing (Zhang et al., 2012). Part of the fresh rhizosphere soil (ca. $30 \mathrm{~g}$ ) was used to measure soil moisture, and the remaining soil was air-dried for measuring soil electrical conductivity, available phosphorus (AP) concentration, and $\mathrm{pH}$.

\subsection{Mycorrhizal colonization}

The roots of chenopods were washed with deionized water. The washed roots were cut into 1-cm-long segments and thoroughly mixed. A sub-sample of $0.5 \mathrm{~g}$ was cleared with $10 \%(\mathrm{w} / \mathrm{v})$ $\mathrm{KOH}$ at $90^{\circ} \mathrm{C}$ in a water bath for 20-30 min and stained with $0.5 \%(\mathrm{w} / \mathrm{v})$ trypan blue. Mycorrhizal colonization $(\mathrm{M} \%)$, arbuscule abundance $(\mathrm{A} \%)$, vesicule abundance $(\mathrm{V} \%)$ and hypha abundance $(\mathrm{H} \%)$ in the root system were calculated according to the method of Trouvelot et al. (1986) using the MYCOCALC program.

DNA was extracted from the plant root samples using a Plant Genomic DNA Kit (Tiangen Biotech Beijing Co., Ltd.). Fungal isolates were identified by the large subunit region (LSU) of ribosomal RNA-targeted nested PCR (Van Tuinen et al., 1998). The first step was performed with the eukaryotic primer pair LR1 and NDLL22 (Van Tuinen et al., 1998), and the PCR products were further amplified in the second step with the AM fungi general primer pair FLR3 and FLR4 (Gollotte et al., 2004).

Five-microliter extract was added to the first step PCR reaction and $1 \mu \mathrm{L}$ of the product was added to the second-step PCR reaction. PCRs were performed at the final volume of $20 \mu \mathrm{L}$ and the cycling conditions were as follows: initial denaturation at $93^{\circ} \mathrm{C}$ for $3 \mathrm{~min}$, then 30 cycles with denaturation at $93^{\circ} \mathrm{C}$ for $40 \mathrm{~s}$, annealing at $54^{\circ} \mathrm{C}$ for $40 \mathrm{~s}$, followed by elongation at $72^{\circ} \mathrm{C}$ for $50 \mathrm{~s}$. The amplification was completed with a final cycle of elongation at $72^{\circ} \mathrm{C}$ for $10 \mathrm{~min}$. The expected length of the PCR products was confirmed by electrophoresis in $1 \%(\mathrm{w} / \mathrm{v})$ denaturing agarose gels in a TAE buffer (Sambrook et al., 1989).

\subsection{Hyphal length density}

Hyphal length density (HLD) from the homogenized soils was measured according to the methods of Jakobsen et al. (1992). The rhizosphere soil was sieved through a 2-mm mesh to 
remove stones and debris and then air-dried. Two-gram dry soil was collected from each soil sample, and the soil was transferred to a grinder with $50 \mathrm{~mL}$ deionized water and then stirred $(4000 \mathrm{rpm})$ for $30 \mathrm{~s}$. The mixture of stirred soil and water was moved into a beaker and stirred for $30 \mathrm{~s}$ using a magnetic stirrer $(900 \mathrm{rpm})$ and then held static for $30 \mathrm{~s}$. Five-milliliter water with hypha was taken from the supernatant, and then filtrated using a $0.45-\mu \mathrm{m}$ membrane. The membrane was stained with trypan blue for observation. HLD was quantified using a compound microscope with a gridded reticule at 250-fold magnification.

\subsection{Measurement of soil characteristics}

Soil moisture was measured using a Diviner 2000 instrument (Beijing Techno Solutions Ltd). The soil electrical conductivity (EC) was measured using DDS-307A Conductivity Meters (Shanghai REX Instrument Factory, China), and soil $\mathrm{pH}$ was measured using a PHS-2F pH meter (Shanghai REX Instrument Factory, China). Soil available phosphorus (AP) was first digested in sulfuric acid and subsequently quantified with an ICP Elemental Analyzer (Bruker Analysis Instrument Ltd., Karlsruhe, BW Germany).

\subsection{Statistical analysis}

The percentage data (including mycorrhizal colonization rate, arbuscule abundance, vesicle abundance, and hypha abundance) were subjected to one-way analysis of variance (ANOVA) using SPSS software version 16.0 (SPSS Inc., Chicago, IL, USA). Critical differences were compared using the least significant difference (LSD) test at $P<0.05$ level.

\section{Results}

\subsection{Mycorrhizal colonization}

The majority of examined chenopod species were colonized by AM fungi at the early growth stage (Fig. 2) and also at the peak growth stage (Fig. 3). The overall mean mycorrhizal colonization rate at the early growth stage was not high, ranging from $5 \%$ to $30 \%$ with a mean of $\sim 10 \%$ (Fig. 2a). The overall arbuscules/coils were rather low with an average of $\sim 2 \%$ (Fig. 2b)
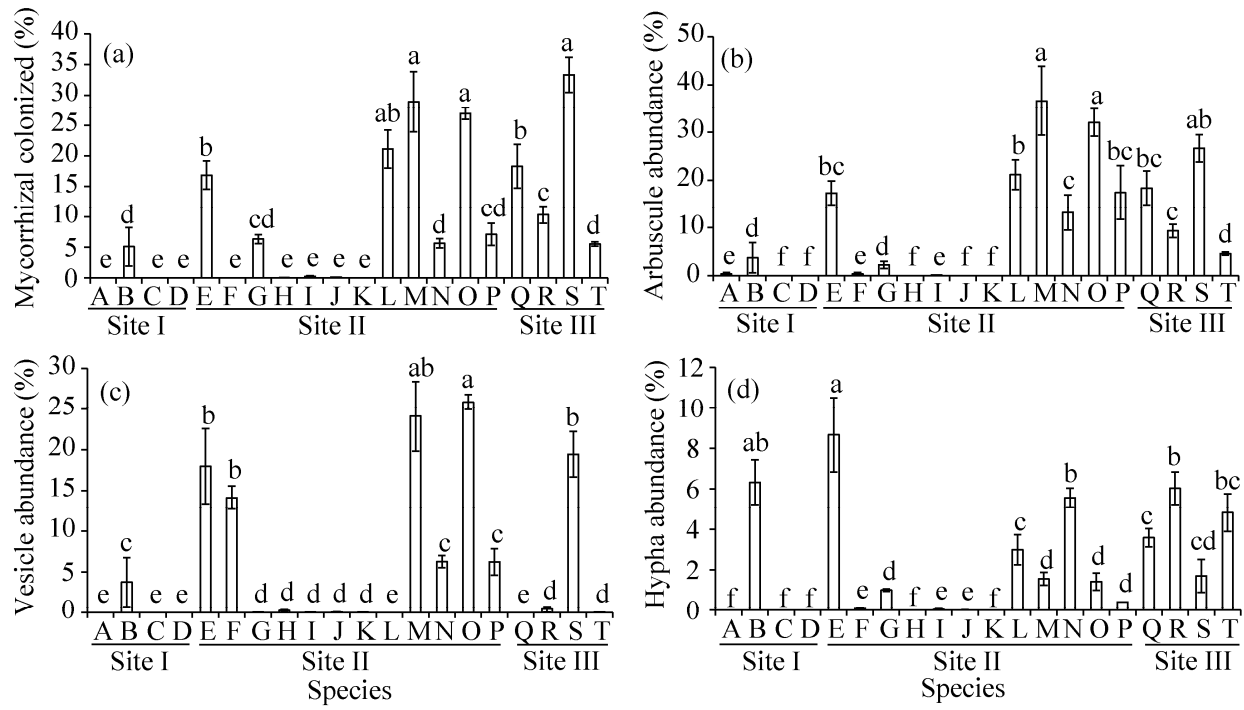

Fig. 2 Mycorrhizae status of arbuscular mycorrhizal fungi in roots of chenopods at early growth stage: (a), mycorrhizal colonization; (b), arbuscule abundance; (c), vesicle abundance; and (d), hyphae abundance. A: C. glaucum; B: K. scoparia; C: S. corniculata; D: S. komarovii; E: S. foliosa; F: S. Collina; G: P. sibirica; H: K. foliatum; I: H. glomeratus; J: S. europaea; K: A. tatarica; L: S. altissima; M: S. acuminate; N: S. physophora; O: S. microphylla; P: S. salsa; Q: P. fertile; R: C. glaucum; S: Chenopodium sp.; T: C. quinoa. The same lowercase letter (e.g., a, b, c, d, e, f) or the same combination of lowercase letters (e.g., ab, bc, cd) in each column represent a high similarity among the different species. Bars indicate standard errors. 
with an exception of S. altissima that had an abundance of $18 \%$. Vesicles were absent or nearly absent from 8 species and the mean abundance was $\sim 24 \%$ (Fig. 2c). Hyphae were absent or nearly absent from 9 species and the mean abundance was $\sim 3.2 \%$ (Fig. 2d). The species-dependency of the mycorrhizal colonization rate at the peak growth period (see Fig. 3a) was quite similar with the species-dependency at the early growth stage (see Fig. 2a). But, in comparison with the species number of completely or nearly completely lack of arbuscules/coils at the early growth stage (8 species), more species (16) were completely or nearly completely lack of arbuscules/coils at the peak growth stage (Fig. 3b). Vesicles were observed in 14 species and the mean abundance was $\sim 38 \%$ at the peak growth stage. The following species significantly increased in the abundances at the peak growth stage (Fig. 3c): K. scoparia; S. foliosa; P. sibirica; S. altissima; S. acuminate; S. physophora; S. microphylla; C. glaucum; and C. Quinoa. The species-dependency of the hypha abundance at the peak growth stage (see Fig. 3d) was also quite similar with the species-dependency at the early growth stage (see Fig. 2d) with a slightly increased mean abundance of $\sim 3.5 \%$. The data mentioned above showed that vesicles were quite common and arbuscules and hyphae were relatively rare. The structural analyses also showed that vesicles can be readily observed in the roots of many chenopod species, especially in S. altissima (Fig. 4a), $S$. foliosa (Fig. 4b), S. acuminate (Fig. 4c), S. salsa (Fig. 4d) and S. microphylla (Fig. 4e).
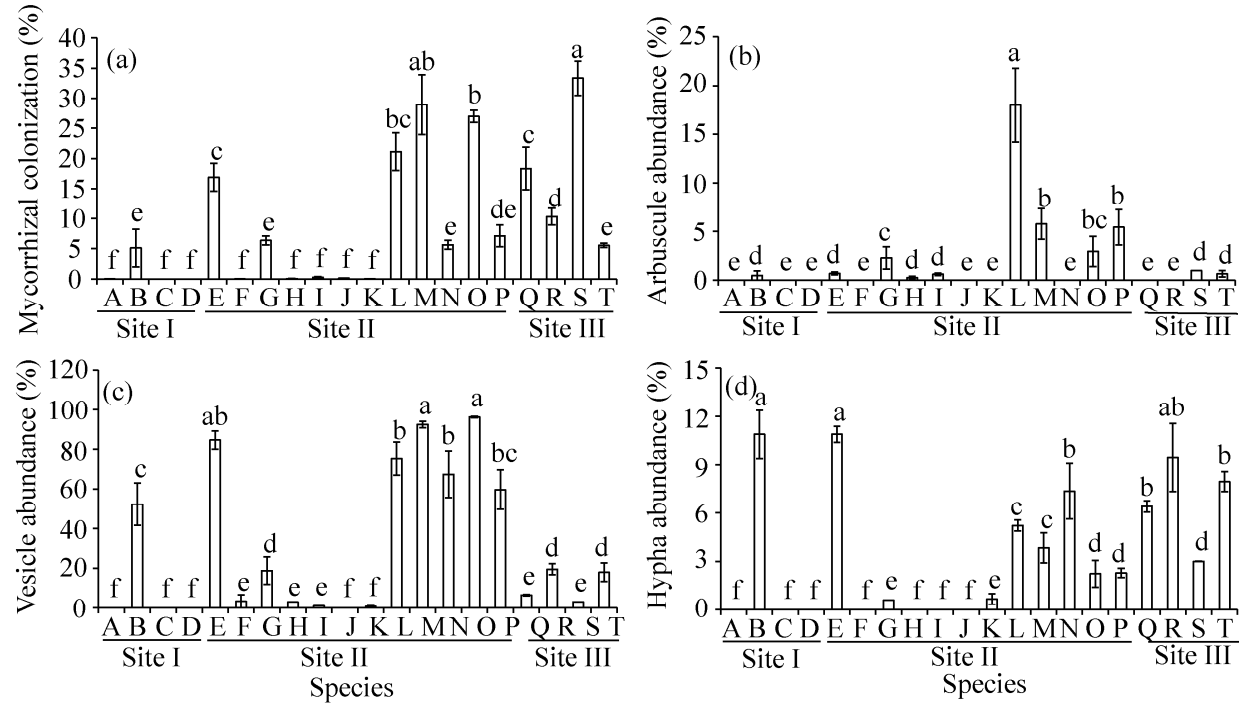

Fig. 3 Mycorrhizae status of arbuscular mycorrhizal fungi in roots of chenopods at peak growth stage: (a), mycorrhizal colonization; (b), arbuscule abundance; (c), vesicle abundance; and (d), hyphae abundance. A: $C$. glaucum; B: K. scoparia; C: S. corniculata; D: S. komarovii; E: S. foliosa; F: S. Collina; G: P. sibirica; H: K. foliatum; I: H. glomeratus; J: S. europaea; K: A. tatarica; L: S. altissima; M: S. acuminate; N: S. physophora; O: S. microphylla; P: S. salsa; Q: P. fertile; R: C. glaucum; S: Chenopodium sp.; T: C. quinoa. The same lowercase letter (e.g., a, b, c, d, e, f) or the same combination of lowercase letters (e.g., ab, bc, cd) in each column represent a high similarity among the different species. Bars indicate standard errors.

\subsection{Hyphal length density}

The hyphal length density (HLD) varied significantly in the rhizosphere soils of different chenopod species. The HLD values in the rhizosphere soils of S. foliosa, S. collina, S. altissima, S. acuminate, S. physophora and S. microphylla were much higher, most of them being greater than $6 \mathrm{~m} / \mathrm{g}$ soil. The HLD values in the rhizosphere soil of C. glaucum, S. corniculata, S. komarovii and S. europaea were very low, being less than $2 \mathrm{~m} / \mathrm{g}$ soil (Fig. 5).

\subsection{Correlations between soil properties and mycorrhizal colonization}

A significant positive correlation was observed between the mycorrhizal colonization in the roots of chenopod species and the soil electrical conductivity $(P<0.01$; Fig. 6a). No significant correlation between the mycorrhizal colonization in the roots of chenopod species and the soil $\mathrm{pH}$ was detected ( $P>0.05$; Fig. 6b). Significant negative correlations of the mycorrhizal colonizations 
in the roots of chenopod species with soil moisture $(P<0.01$; Fig. 6c) and available $P$ concentration $(P<0.01$; Fig. 6 d) were observed.

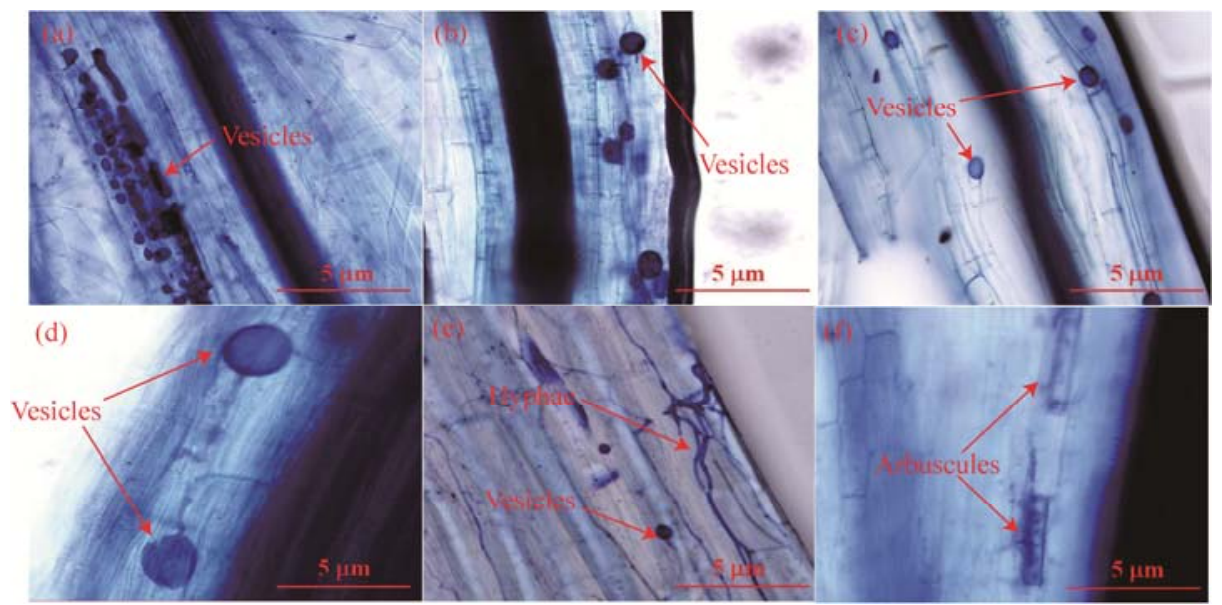

Fig. 4 AM fungal structures in the roots of Suaeda altissima (a, 400-fold), Salsola foliosa (b, 400-fold), Suaeda acuminate (c, 400-fold), Suaeda salsa (d, 400-fold), Suaeda microphylla (e, 400-fold) and Polygonum fertile (f, 400-fold)

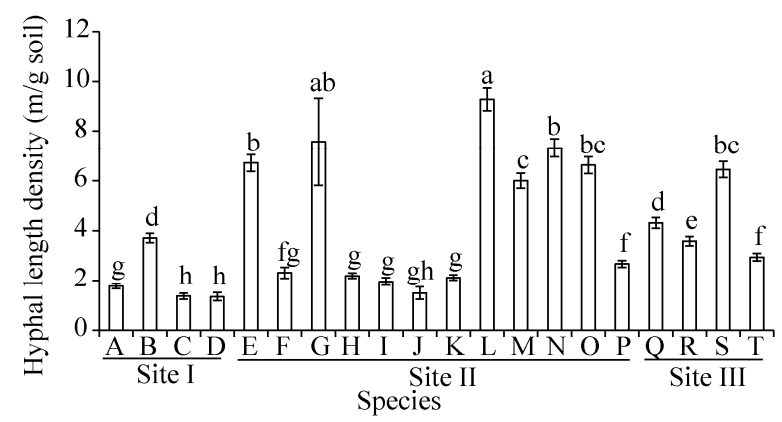

Fig. 5 Hyphal length density in the rhizosphere soil of chenopds. A: C. glaucum; B: K. scoparia; C: S. corniculata; D: S. komarovii; E: S. foliosa; F: S. Collina; G: P. sibirica; H: K. foliatum; I: H. glomeratus; J: S. europaea; K: A. tatarica; L: S. altissima; M: S. acuminate; N: S. physophora; O: S. microphylla; P: S. salsa; Q: P. fertile; R: C. glaucum; S: Chenopodium sp.; T: C. Quinoa. The same lowercase letter (e.g., b, c, d, e, f, g, h) or the same combination of lowercase letters (e.g., ab, bc, fg, gh) in each column represent a high similarity among the different species. Bars indicate standard error.
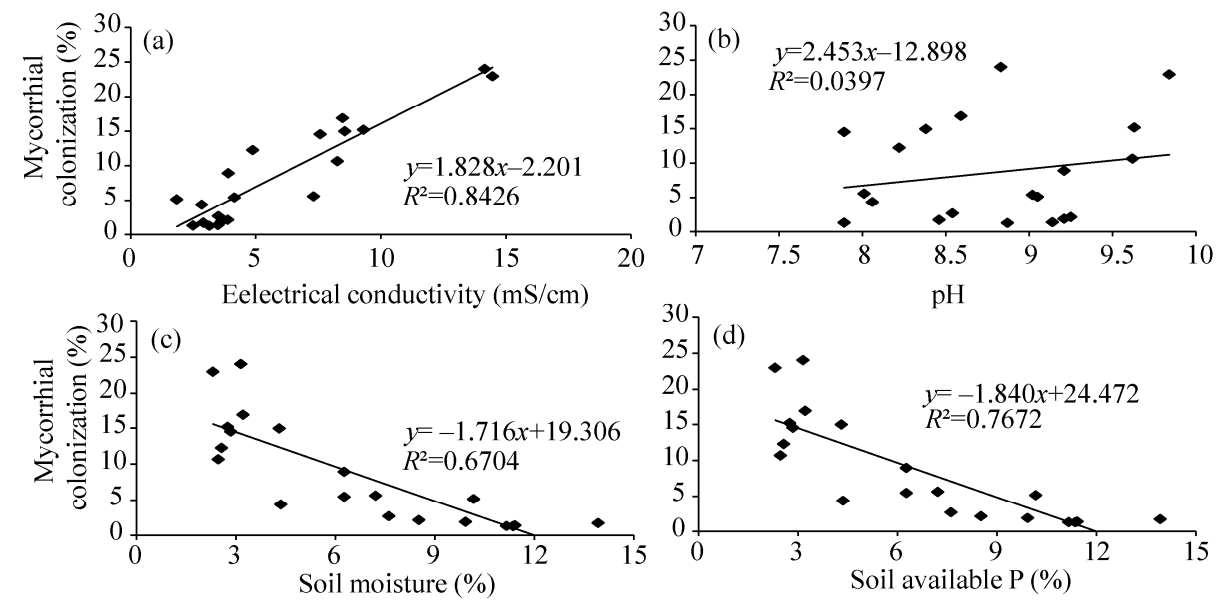

Fig. 6 Correlations of mycorrhizal colonization in the root systems of chenopod species with soil electrical conductivity (a), $\mathrm{pH}$ (b), soil moisture (c), and soil available P (d) 


\section{Discussion}

This study observed the mycorrhizal structure in the root systems of many chenopod plant species in three saline habitats: a saline alkaline meadow in the Songnen Plain of northeastern China, a saline desert in the Junggar Basin of northwestern China, and a saline alpine meadow in the Tibetan Plateau of western China. We found that approximately $60 \%$ of the total 20 chenopod plant species were colonized by AM fungi, being consistent with previous observations of AM structures in the root systems of other chenopod species (Hirrel et al., 1978; Allen, 1983; Allen and Allen, 1990; Sigüenza et al., 1996; Asghari et al., 2005; Plenchette and Duponnois, 2005; Püschel et al., 2007; Aleman and Tiver, 2010; Zhang et al., 2012). In previous studies, arbuscule formed within root cortical cells was often considered as one of the most important characteristics of mycorrhizal plants (Smith and Read, 2008) and the arbuscule structure was observed in the root of chenopod species in South Australia (Asghari et al., 2005; Aleman and Tiver, 2010). Moreover, arbuscule is often considered as a primary functional interface of the symbiosis and is important to carbon (C) and phosphorus (P) exchanges in the root (Smith and Read, 2008; Selosse and Rousset, 2011). However, the present study shows that the arbuscule/coil structures were rarely present in the roots of these twenty chenopod species. In contrast, a large number of vesicles were observed in the root systems of chenopod species, being in agreement with the observations in the Ganges River basin of India (Sengupta and Chaudhuri, 1990), in the Kaolack of Senegal (Plenchette and Duponnois, 2005) and in the Gurbantunggut Desert in China (Zhang et al., 2012). The rare presence of arbuscule in these studied chenopods might be related to the physiological and ecological characteristics of chenopods and the environmental conditions in the investigated three saline habitats. The previous studies have shown that the AM hyphal branches pass into the middle and inner cortex of the roots and grow longitudinally in the intercellular spaces, and then form arbuscule (Smith and Read, 2008). The growth rates of the intercellular hyphae were species-dependent (Bruce et al., 1994) and constrained by such factors as nutrient deficiencies, drought stress, low temperature or waterlogging (Smith and Read, 2008).

The present study demonstrated that mycorrhizal colonization in the root of chenopods can occur at the early growth stage and at the peak growth period, and our previous studies demonstrated that mycorrhizal colonization can also occur at the late growth stage (Shi et al., 2006; Zhang et al., 2012), being supportive to the reported phenological stages of the mycorrhizal colonization in the root of chenopods (Allen, 1983; Sigüenza et al., 1996). The results suggest that the phenology of the 20 chenopods had no impact on the formation of mycorrhizal structures. The results lend a strong support to the proposition that AM fungi might have played an important role in uptake of nutrients and/or water, in alleviating salt stress during the whole life cycle of chenopods (Kiers et al., 2011).

Previous studies have found that most chenopod species prefer to grow in saline conditions and AM fungi can colonize chenopod species (Barrow et al., 1997; Hildebrandt et al., 2001; Wilde et al., 2009). The observed robust correlation between the mycorrhizal colonization and the soil electrical conductivity implies that the ecological function of AM fungi on the growth of chenopods might not be related to nutrient uptake but rather to reduction in salt stress, being supportive to previous reports that AM fungi can alleviate the salt stress of chenopod species (Asghari et al., 2005; Plenchette and Duponnois, 2005; Evelin et al., 2009). The observed negative correlation between the mycorrhizal colonization in the roots of chenopod species and available $\mathrm{P}$ concentration in the present study also lends a strong support to the previous reports that high soil available $\mathrm{P}$ concentrations can suppress mycorrhizal colonization and reduce the effect of AM fungi on plant growth (Raznikiewicz et al., 1994; Ingleby et al., 2001; Bouwmeester et al., 2007; Nogueira and Cardoso, 2007; Yoneyama et al., 2007; Balzergue et al., 2011; Camenzind et al., 2014).

High soil $\mathrm{pH}$ was reportedly able to reduce the AM fungal spore germination (Hepper, 1984), thus discouraging mycorrhizal colonization (Aliasgharzadeh et al., 2001; Olsson and Tyler, 2004). But, this present study did not show any significant correlation between the mycorrhizal colonization of the studied chenopod species and soil $\mathrm{pH}$, being completely at odd with many 
other observations (Reddy and Verma, 1981; Coughlan et al., 2000; Oehl et al., 2005; Kittiworawat et al., 2010; Varga and Kytöviita, 2010). This discrepancy might be resulted from the fact that the $\mathrm{pH}$ gradient in the soils of the studied 20 chenopods was not large enough. In addition, we found that soil moisture had a negative effect on the mycorrhizal colonization in chenopod roots and that the average mycorrhizal colonization in chenopods of site I (Songnen Plain) was much lower than those in sites II (Junggar Desert) and III (Tibetan Plateau), suggesting that mycorrhizal colonization in chenopod roots might prefer to drought stress, being quite similar to the previous results observed from two grasses, Agropyron smithii and A. dasystachyum (Allen and Allen, 1986).

\section{Conclusions}

We found approximately $60 \%$ of the studied twenty chenopod species in three different saline conditions (a saline alkaline meadow in the Songnen Plain of northeastern China, a saline desert in the Junggar Basin of northwestern China, and a saline alpine meadow in the Tibetan Plateau of western China) were colonized by AM fungi. Vesicle structures were commonly observed in the roots of chenopods, but arbuscules or hyphal coils were relatively rarely observed. A significant positive correlation between the soil electrical conductivity and mycorrhizal colonization and negative correlations of mycorrhizal colonization with the soil available phosphorus (AP) concentration and soil moisture were observed. The results imply that some chenopods can form mycorrhizal symbiosis with AM fungi and the symbiosis is controlled by soil available $\mathrm{P}$ concentration, soil moisture, and soil electrical conductivity. The documented mycorrhizal association between chenopods and AM fungi may be useful for improving the adaptability of chenopods to salt and drought stresses.

\section{Acknowledgements}

This research was supported by the National Natural Science Foundation of China (31300097, 31470405), and the Foundation of Jilin Provincial Education Department and the China Scholarship Council (201506625023). We thank Dr. CAI Xiaobu and Dr. ZHANG Ke for their help with field work.

\section{References}

Aguilera L E, Gutierrez J R, Moreno R J. 1998. Vesiculo arbuscular mycorrhizae associated with saltbushes Atriplex spp. (Chenopodiaceae) in the Chilean arid zone. Revista Chilena de Historia Natural, 71: 291-302.

Aleman R, Tiver F. 2010. Endomycorrhizal infection levels among chenopod plant species at port wakefield, south Australia. Transactions of the Royal Society of South Australia, 134(1): 1-4.

Aliasgharzadeh N, Rastin S N, Towfighi H, et al. 2001. Occurrence of arbuscular mycorrhizal fungi in saline soils of the Tabriz Plain of Iran in relation to some physical and chemical properties of soil. Mycorrhiza, 11(3): 119-122.

Allen E B, Allen M F. 1986. Water relations of xeric grasses in the field: interactions of mycorrhizas and competition. New Phytologist, 104(4): 559-571.

Allen M F. 1983. Formation of vesicular-arbuscular mycorrhizae in Atriplex gardneri (Chenopodiaceae): seasonal response in a cold desert. Mycologia, 75(5): 773-776.

Allen M F, Allen E B. 1990. Carbon source of VA mycorrhizal fungi associated with Chenopodiaceae from a semiarid shrub-steppe. Ecology, 71(5): 2019-2021.

Asghari H R, Marschner P, Smith S E, et al. 2005. Growth response of Atriplex nummularia to inoculation with arbuscular mycorrhizal fungi at different salinity levels. Plant and Soil, 273(1-2): 245-256.

Balzergue C, Puech-Pagès V, Bécard G, et al. 2011. The regulation of arbuscular mycorrhizal symbiosis by phosphate in pea involves early and systemic signalling events. Journal of Experimental Botany, 62(3): 1049-1060.

Barrow J R, Havstad K M, McCaslin B D. 1997. Fungal root endophytes in fourwing saltbush, Atriplex canescens, on arid rangelands of southwestern USA. Arid Soil Research and Rehabilitation, 11(2): 177-185.

Bouwmeester H J, Roux C, Lopez-Raez J A, et al. 2007. Rhizosphere communication of plants, parasitic plants and AM fungi. Trends in Plant Science, 12(5): 224-230.

Bruce A, Smith S E, Tester M. 1994. The development of mycorrhizal infection in cucumber: effects of P supply on root growth, 
formation of entry points and growth of infection units. New Phytologist, 127(3): 507-514.

Camenzind T, Hempel S, Homeier J, et al. 2014. Nitrogen and phosphorus additions impact arbuscular mycorrhizal abundance and molecular diversity in a tropical montane forest. Global Change Biology, 20(12): 3646-3659.

Chandrasekaran M, Boughattas S, Hu S J, et al. 2014. A meta-analysis of arbuscular mycorrhizal effects on plants grown under salt stress. Mycorrhiza, 24(8): 611-625.

Coughlan A P, Dalpé Y, Lapointe L, et al. 2000. Soil pH-induced changes in root colonization, diversity, and reproduction of symbiotic arbuscular mycorrhizal fungi from healthy and declining maple forests. Canadian Journal of Forest Research, 30(10): 1543-1554.

Daleo P, Fanjul E, Casariego A M, et al. 2007. Ecosystem engineers activate mycorrhizal mutualism in salt marshes. Ecology Letters, 10(10): 902-908.

Evelin H, Kapoor R, Giri B. 2009. Arbuscular mycorrhizal fungi in alleviation of salt stress: a review. Annals of Botany, 104(7): 1263-1280.

Glenn E P, O'Leary J W, Watson M C, et al. 1991. Salicornia bigelovii Torr.: an oilseed halophyte for seawater irrigation. Science, 251(4997): 1065-1067.

Gollotte A, van Tuinen D, Atkinson D. 2004. Diversity of arbuscular mycorrhizal fungi colonizing roots of the grass species Agrostis capillaris and Lolium perenne in a field experiment. Mycorrhiza, 14(2): 111-117.

Hepper C M. 1984. Regulation of spore germination of the vesicular-arbuscular mycorrhizal fungus Acaulospora laevis by soil $\mathrm{pH}$. Transactions of the British Mycological Society, 83(1): 154-156.

Hildebrandt U, Janetta K, Ouziad F, et al. 2001. Arbuscular mycorrhizal colonization of halophytes in Central European salt marshes. Mycorrhiza, 10(4): 175-183.

Hirrel M C, Mehravaran H, Gerdemann J W. 1978. Vesicular-arbuscular mycorrhizae in the Chenopodiaceae and Cruciferae: do they occur?. Canadian Journal of Botany, 56(22): 2813-2817.

Hodge A, Fitter A H. 2010. Substantial nitrogen acquisition by arbuscular mycorrhizal fungi from organic material has implications for N cycling. Proceedings of the National Academy of Sciences of the United States of America, 107(31): 13754-13759.

Ingleby K, Fahmer A, Wilson J, et al. 2001. Interactions between mycorrhizal colonisation, nodulation and growth of Calliandra calothyrsus seedlings supplied with different concentrations of phosphorus solution. Symbiosis, 30(1): 15-28.

Jakobsen I, Abbott L K, Robson A D. 1992. External hyphae of vesicular-arbuscular mycorrhizal fungi associated with Trifolium subterraneum L. 2. Hyphal transport of ${ }^{32} \mathrm{P}$ over defined distances. New Phytologist, 120(4): 509-516.

Kiers E T, Duhamel M, Beesetty Y, et al. 2011. Reciprocal rewards stabilize cooperation in the mycorrhizal symbiosis. Science, 333(6044): 880-882.

Kittiworawat S, Youpensuk S, Rerkasem B. 2010. Diversity of arbuscular mycorrhizal fungi in Mimosa invisa and effect of the soil $\mathrm{pH}$ on the symbiosis. Chiang Mai Journal of Science, 37(3): 517-527.

Miransari M. 2011. Arbuscular mycorrhizal fungi and nitrogen uptake. Archives of Microbiology, 193(2): 77-81.

Mohan J E, Cowden C C, Baas P, et al. 2014. Mycorrhizal fungi mediation of terrestrial ecosystem responses to global change: mini-review. Fungal Ecology, 10: 3-19.

Nazeri N K, Lambers H, Tibbett M, et al. 2014. Moderating mycorrhizas: arbuscular mycorrhizas modify rhizosphere chemistry and maintain plant phosphorus status within narrow boundaries. Plant, Cell and Environment, 37(4): 911-921.

Nogueira M A, Cardoso E J N. 2007. Phosphorus availability changes the internal and external endomycorrhizal colonization and affects symbiotic effectivenes. Scientia Agricola, 64(3): 295-300.

Oehl F, Redecker D, Sieverding E. 2005. Glomus badium, a new sporocarpic mycorrhizal fungal species from European grasslands with higher soil pH. Journal of Applied Botany and Food Quality, 79(1): 38-43.

Olsson P A, Tyler G. 2004. Occurrence of non-mycorrhizal plant species in south Swedish rocky habitats is related to exchangeable soil phosphate. Journal of Ecology, 92(5): 808-815.

Pennisi E. 2004. The secret life of fungi. Science, 304(5677): 1620-1622.

Plenchette C, Duponnois R. 2005. Growth response of the saltbush Atriplex nummularia L. to inoculation with the arbuscular mycorrhizal fungus Glomus intraradices. Journal of Arid Environments, 61(4): 535-540.

Porcel R, Ruiz-Lozano J M. 2004. Arbuscular mycorrhizal influence on leaf water potential, solute accumulation, and oxidative stress in soybean plants subjected to drought stress. Journal of Experimental Botany, 55(403): 1743-1750.

Püschel D, Rydlová J, Vosátka M. 2007. Mycorrhiza influences plant community structure in succession on spoil banks. Basic and Applied Ecology, 8(6): 510-520.

Raznikiewicz H, Carlgren K, Maartensson A. 1994. Impact of phosphorus fertilization and liming on the presence of arbuscular mycorrhizal spores in a Swedish long-term field experiment. Swedish Journal of Agricultural Research, 24: 157-164. 
Reddy M V, Verma N K. 1981. Aphid-mycorrhizal association, and its relationship with the rhizosphere-soil pH. Comparative Physiology and Ecology, 6(3): 157-158.

Rodriguez A, Sanders I R. 2015. The role of community and population ecology in applying mycorrhizal fungi for improved food security. The ISME Journal, 9(5): 1053-1061.

Ruíz-Sánchez M, Armada E, Muñoz Y, et al. 2011. Azospirillum and arbuscular mycorrhizal colonization enhance rice growth and physiological traits under well-watered and drought conditions. Journal of Plant Physiology, 168(10): 1031-1037.

Sambrook J, Fritsch E F, Maniatis T. 1989. Molecular Cloning: A Laboratory Manual (2 ${ }^{\text {nd }}$ ed.). New York: Cold Spring Harbor Laboratory Press, 202-203.

Selosse M A, Rousset F. 2011. The plant-fungal marketplace. Science, 333(6044): 828-829.

Sengupta A, Chaudhuri S. 1990. Vesicular arbuscular mycorrhiza (VAM) in pioneer salt marsh plants of the Ganges river delta in west Bengal (India). Plant and Soil, 122(1): 111-113.

Shi Z Y, Feng G, Christie P, et al. 2006. Arbuscular mycorrhizal status of spring ephemerals in the desert ecosystem of Junggar Basin, China. Mycorrhiza, 16(4): 269-275.

Shi Z Y, Mickan B, Feng G, et al. 2015. Arbuscular mycorrhizal fungi improved plant growth and nutrient acquisition of desert ephemeral Plantago minuta under variable soil water conditions. Journal of Arid Land, 7(3): 414-420.

Sigüenza C, Espejel I, Allen E B. 1996. Seasonality of mycorrhizae in coastal sand dunes of Baja California. Mycorrhiza, 6(2): 151-157.

Smith F A, Grace E J, Smith S E. 2009. More than a carbon economy: nutrient trade and ecological sustainability in facultative arbuscular mycorrhizal symbioses. New Phytologist, 182(2): 347-358.

Smith S E, Read D J. 2008. Mycorrhizal Symbiosis ( $3^{\text {rd }}$ ed.). Amsterdam, Boston: Academic Press, 26-27.

Smith S E, Jakobsen I, Grønlund M, et al. 2011. Roles of arbuscular mycorrhizas in plant phosphorus nutrition: interactions between pathways of phosphorus uptake in arbuscular mycorrhizal roots have important implications for understanding and manipulating plant phosphorus acquisition. Plant Physiology, 156(3): 1050-1057.

Trouvelot A, Kough J L, Gianinazzi-Pearson V. 1986. Mesure du taux de mycorhization VA d'un système radiculaire. Recherche de méthodes d'estimation ayant une signification fonctionnelle. In: Gianinazzi-Pearson V, Gianinazzi S. Physiological and Genetical Aspects of Mycorrhizae: Proceedings of the 1st European Symposium on Mycorrhizae. Paris: INRA Press, 217-221.

van der Heijden M G A, Streitwolf-Engel R, Riedl R, et al. 2006. The mycorrhizal contribution to plant productivity, plant nutrition and soil structure in experimental grassland. New Phytologist, 172(4): 739-752.

Van Tuinen D, Jacquot E, Zhao B, et al. 1998. Characterization of root colonization profiles by a microcosm community of arbuscular mycorrhizal fungi using 25S rDNA-targeted nested PCR. Molecular Ecology, 7(7): 879-887.

Varga S, Kytöviita M M. 2010. Interrelationships between mycorrhizal symbiosis, soil pH and plant sex modify the performance of Antennaria dioica. Acta Oecologica, 36(3): 291-298.

Wagg C, Bender S F, Widmer F, et al. 2014. Soil biodiversity and soil community composition determine ecosystem multifunctionality. Proceedings of the National Academy of Sciences of the United States of America, 111(14): 5266-5270.

Whiteside M D, Digman M A, Gratton E, et al. 2012. Organic nitrogen uptake by arbuscular mycorrhizal fungi in a boreal forest. Soil Biology and Biochemistry, 55: 7-13.

Wilde P, Manal A, Stodden M, et al. 2009. Biodiversity of arbuscular mycorrhizal fungi in roots and soils of two salt marshes. Environmental Microbiology, 11(6): 1548-1561.

Williams S E, Wollum A G, Aldon E F. 1974. Growth of Atriplex canescens (Pursh) Nutt. improved by formation of vesicular-arbuscular mycorrhizae. Soil Science Society of America Journal, 38(6): 962-965.

Yoneyama K, Yoneyama K, Takeuchi Y, et al. 2007. Phosphorus deficiency in red clover promotes exudation of orobanchol, the signal for mycorrhizal symbionts and germination stimulant for root parasites. Planta, 225(4): 1031-1038.

Zhang T, Shi N, Bai D S, et al. 2012. Arbuscular mycorrhizal fungi promote the growth of Ceratocarpus arenarius (Chenopodiaceae) with no enhancement of phosphorus nutrition. PLoS ONE, 7(9): e41151. 